$$
\begin{aligned}
& \text { دور أنثطة إدارات العلاقات العامة في الوحدات المحلية في التوعية البيئية لقاطنى الريف المصري } \\
& \text { اسماء صابر الطنطاوى , هناء السيد محمدץ, محمد احمد الحويطى } \\
& \text { 1-باحث ـ معهد الدر اسات والبحوث البيئية ـ جامعة مدينة السادات }
\end{aligned}
$$

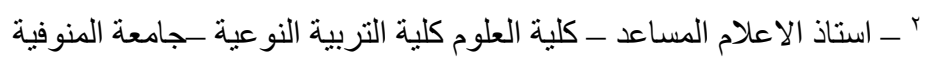

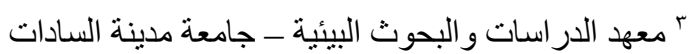

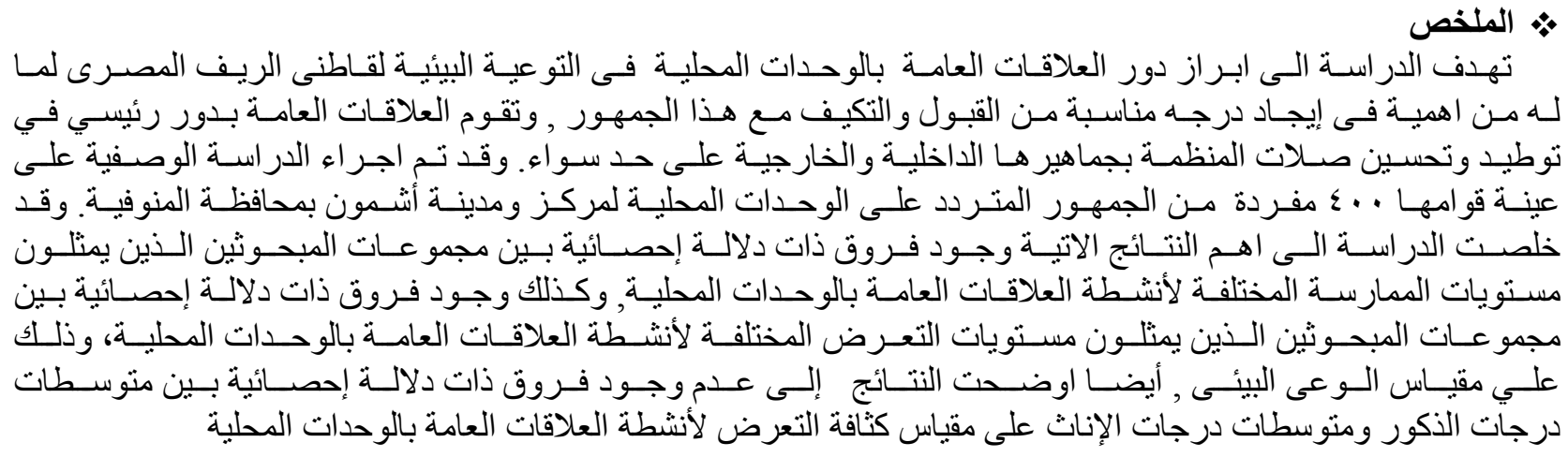

\title{
Abstract
}

The study aims to highlight the role of public relations in the local units in the environmental awareness of the rural Egyptian population because it is important in finding an appropriate degree of acceptance and adaptation to this public. Public relations plays a key role in consolidating and improving the links of the organization to its internal and external audiences alike. The descriptive study was conducted on a sample of 400 individuals from the general public on the local units of the center and city of Ashmoun in Menoufia governorate. The study found that there were statistically significant differences between the groups of respondents who represent the different levels of practice of the public relations activities in the local units, as well as the existence of statistically significant differences among the groups of respondents who represent the different levels of exposure of public relations activities in the local units. The results also showed that there were no statistically significant differences between male and female mean scores on the exposure intensity scale for public relations activities in local units.

العلاقات العامة إحدى وظائف المنظمة التي تهدف من خلالها إلى تحقيق مجمو عه من الصلات المنات العبادلة مع جمهورها

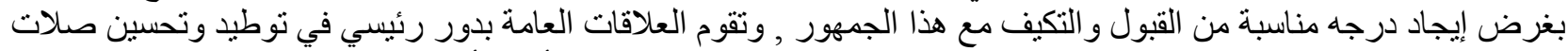

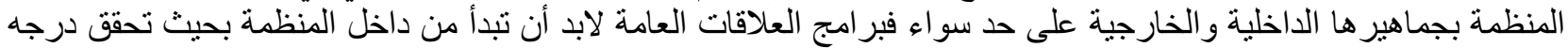

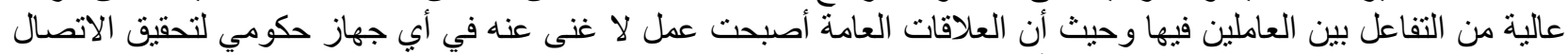

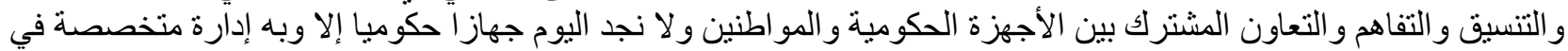

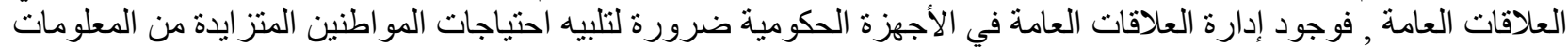

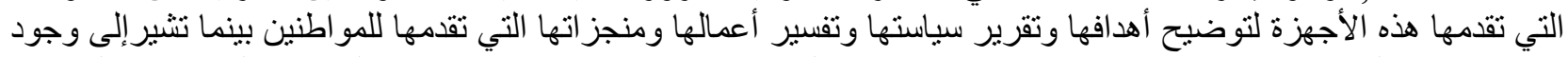

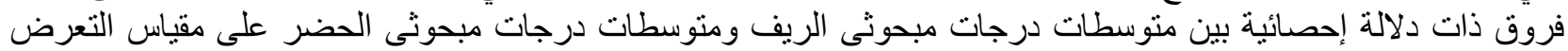

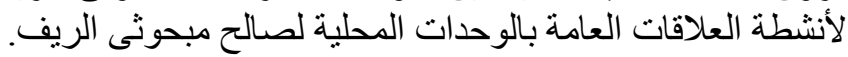

\section{مشكله الاراسة}

تو اجه العلاقات العامة العديد من المشكلات التي تؤثر على علاقتها بالجمهور و على ثقته فيها وذللك يرجع لأسباب كثيرة

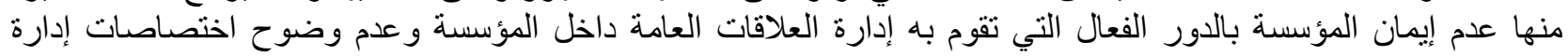




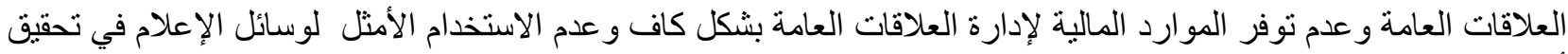

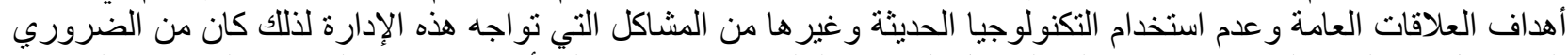

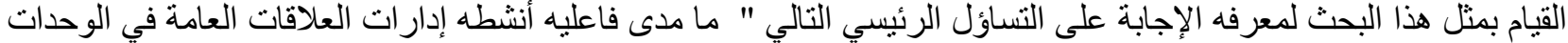

المحلية ودور ها في التو عية البيئية في الريف المصابة المصري" ؟

أهميه الدراسة

تتبثث أهميه البحث والدراسة في نوعين من الأهمية كما يلي :

الأهمية العظمية

وتتبلور الأهمية العلمية فيما يلي :

- - ماعليه أنشطه العلاقات العامة التي نقدم من خلال إدارات العلاقات العامة بالوحدات المحلية .

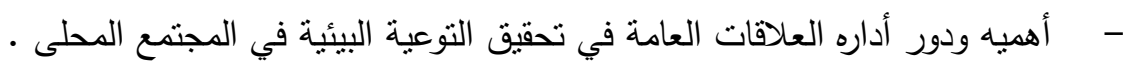

- - - الروية المستقلية لإدارات العلاقات العامة بالوحدات المحلية والخطط المفعلة للوعي البيئي.

- - قد تدفع هذه الدراسة باحثين آخرين من ذات التخصص أو من تخصص آخر للاهنمام بدراسة أنشطه العلاقات العامة ودورها في التوعية البيئية في الريف المصري من منظور آخر وهذا يؤدى إلى تراكم معرفي يمكن أن يفيد العاملين في

هذا المجال .

- يشكل هذا البحث محاوله للكثف عن أهيه تفعيل الأنشطة المختلفة لإدارة العلاقات العامة من اجل خدمه البيئة .

الأهمية التطبيقية

وتتبلور الأهية التطبيقية فيما يلي :

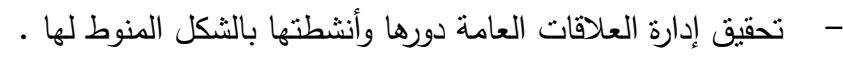

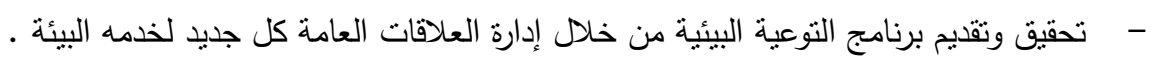

- - تحقيق الاستفادة الكاملة لأكبر عدد ممكن من المجتمع المحلى من خلال برامج التوعية البيئية المقدمة إليه .

أهداف الدراسة

تهدف الدراسة إلى محاوله التعرف على دور أنشطة إدارات العلاقات في الوحدات المحلية في التوعية البيئية للريف المصري .

حدود الاراسة

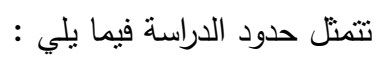

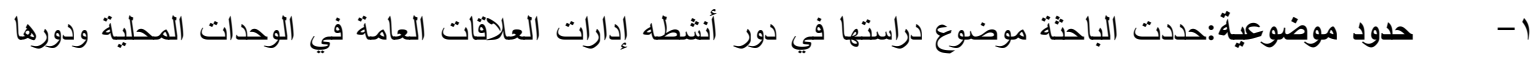

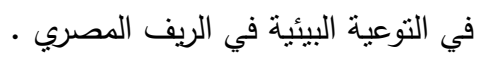

r- - مدود مكانية :تتمثل حدود الدراسة المكانية في الوحدة المحلية لمركز ومدينه أثنمون والوحدات التابعة لها وهم 10

وحده محليه تابعة لمركز ومدينة أشثون بمحافظه المنوفية

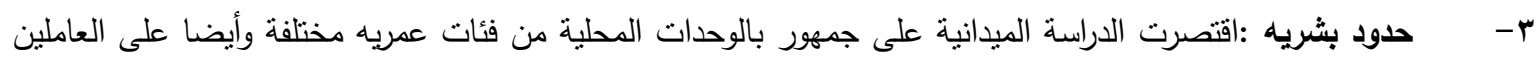

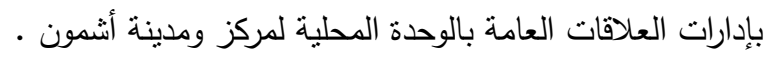


الاراسات السابقة

تتكلل الدراسات السابقة محور هام في معظم البحوث والدراسات وذللك حيث يقوم الباحث من خلالها بالتعرف على كثير من الطرق والإجراءات المنهجية التي تساعده على تحديد مشكله البحث وصياغة الأهداف والتساؤلات والإجراءات الدنهجية الخاصة

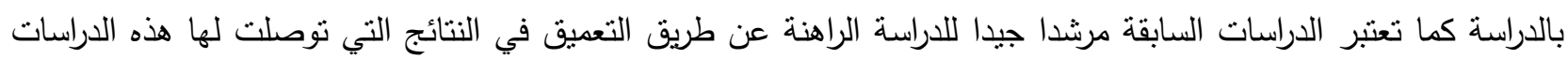

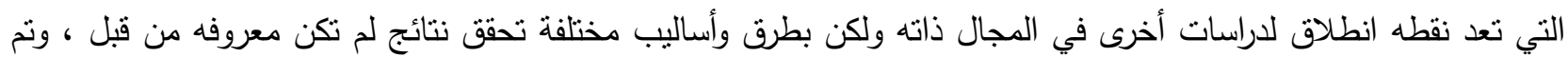
تقسيم هذه الدراسات إلى محورين : المحور الأول : دراسات تتاولت العلاقات العامة ، المحور الثاني :دراسات تتاولت العلاقات

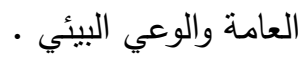

\section{المحور الاول: دراسات تناولت العلاقات العامة}

توصلت دراسة جدعان قاضل الثمري 17 أب م بعنوان ' "دور العلاقات العامة فى دعم جهود خطه التنمية الوطنية بدولة الكويت " إلى قلة عدد المتخصصين في مجال العلاقات العامة والإعلام من ضباط العاط ومهنيين و أفراد داخل إدارة العلاقات العات العامة

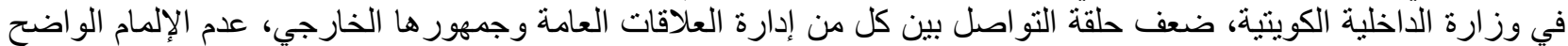

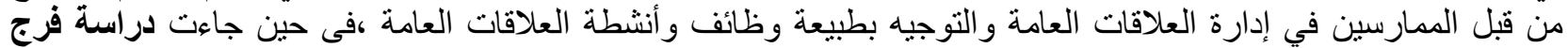

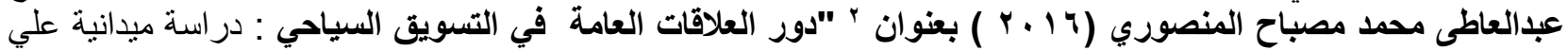

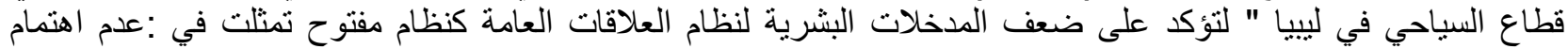

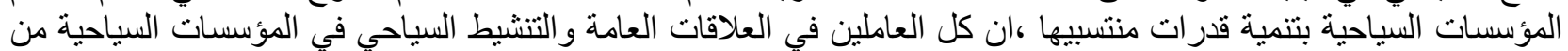

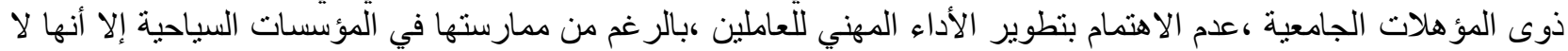

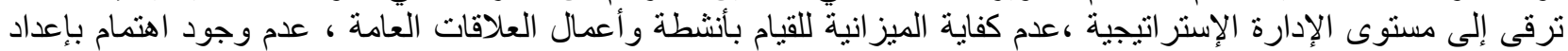

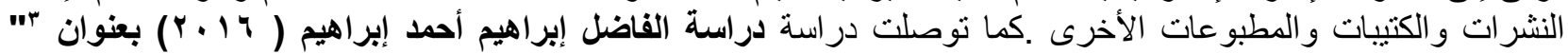

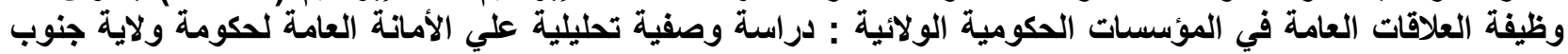

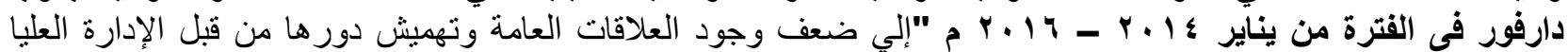

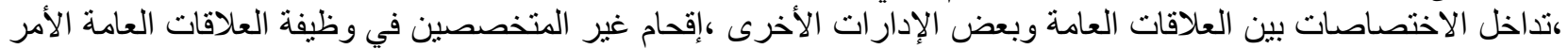

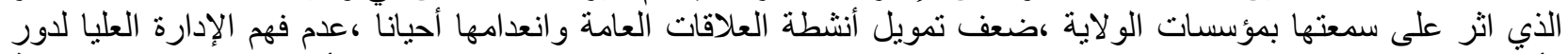

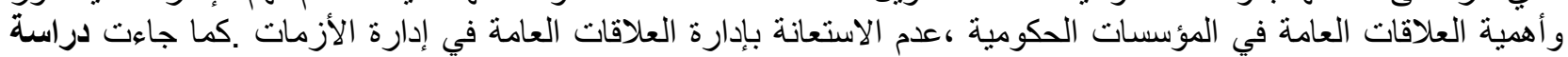

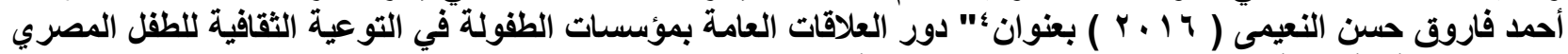

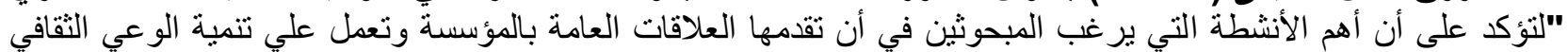

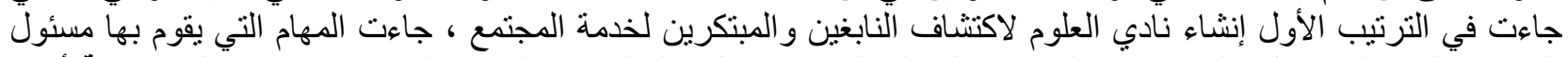

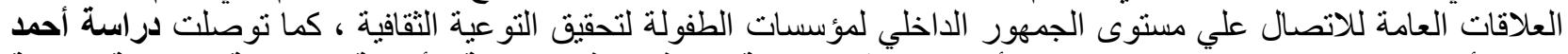

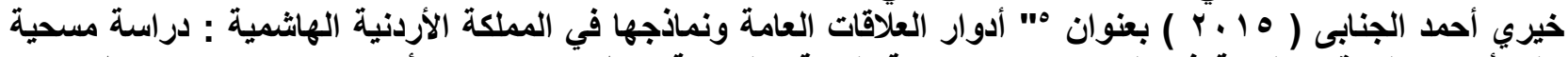

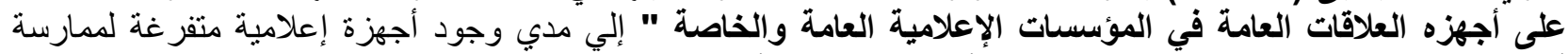

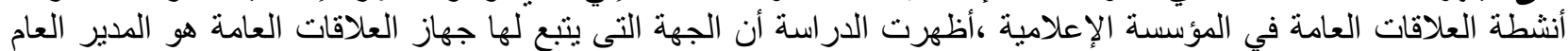

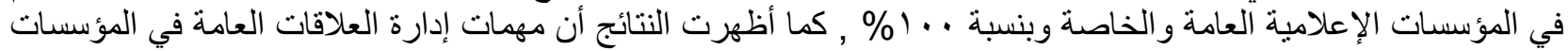

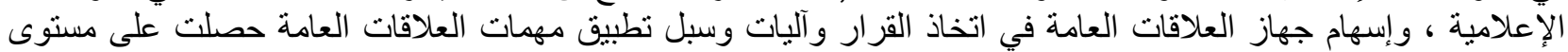

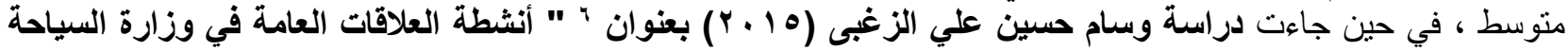

'جدعان قاضل الثمرى ، دور العلاقات العامة في دعم جهود خطة التتمية الوطنية بدوله الكويت دراسة تحليلية ميدانية ، رسالة دكتور اه ، كلية الاداب ،

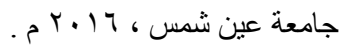

r فرج عبدالعاطى محمد مصباح المنصوري ، دور العلاقات العامة في التسويق السياحي : در اسة ميدانية علي قطاع السياحي في ليبيا ، رسالة دكتور اه ،

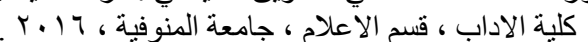

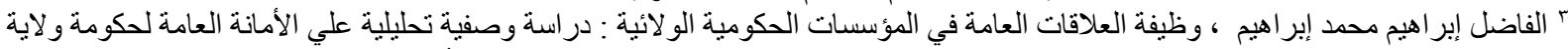

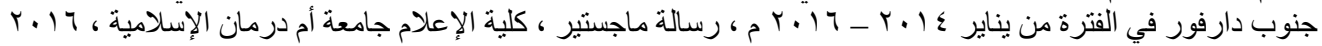

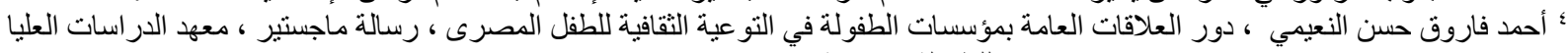

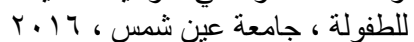

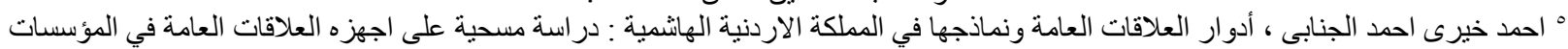

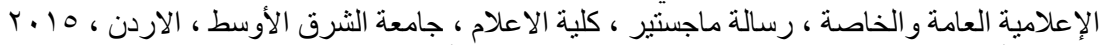

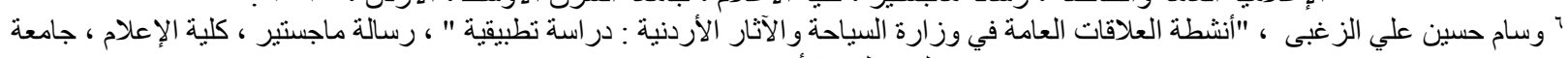

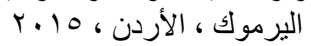


والآثار الأردنية : دراسة تطبيقية " لنؤكد على أنه أظهرت النتائج ضعف الموازنات المالية المالية للقيام بالحملات الإعلامية

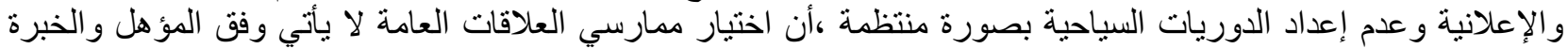

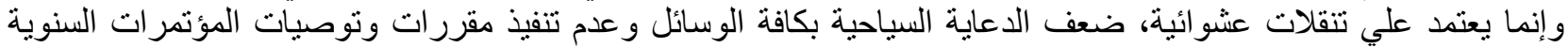

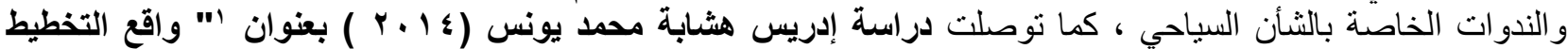

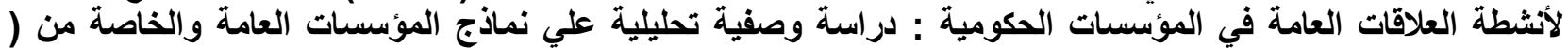

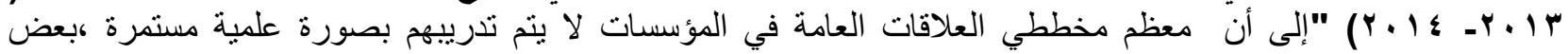

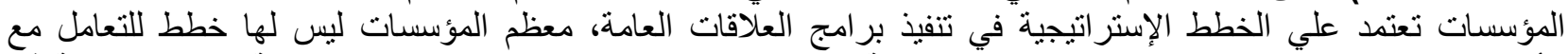

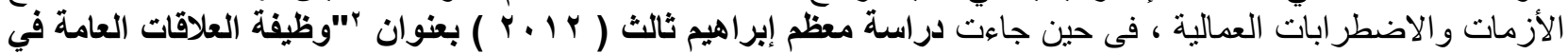

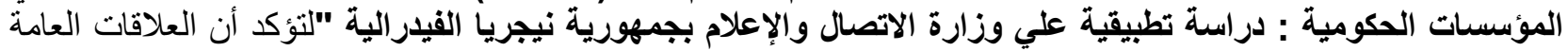

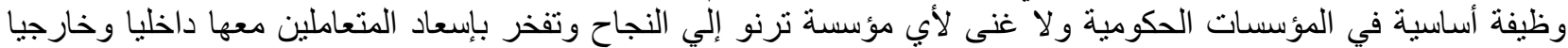
إلى أن تأخذ بالعلاقات العامة بثوبها الجديد و الحد

المحور الثاني :دراسات تناولت العلاقات العامة والوعي البيئي

توصلت دراسة جلال محمد يس جلال (\& 1 ب ) بعنوان" " دور الإعلام في تنمية الوعي البيئي : دراسة تحليلية علي إذاعة

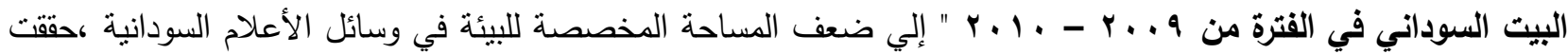

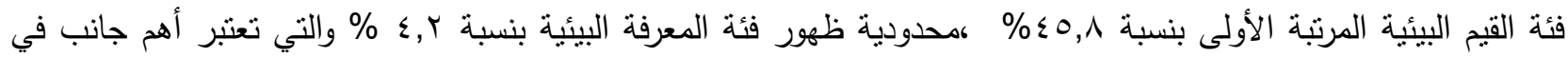

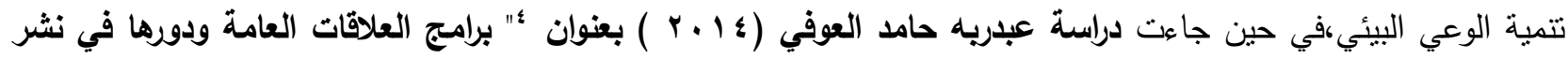
الوعي البيئي بالمجتمع السعودي: الرئاسة العامة للأرصاد وحماية البيئة أنموذجا لتؤكد انه يوجد العديد من معوقات العات البرامج البيئية للعلاقات العامة تتمتل في عدم تقهم الممارسين للعلاقات العامة بوظائفهم تجاه نشر الوعي البيئي وممارستها بشكل كامل

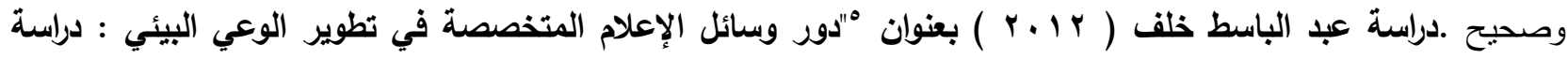
تطبيقية علي طلبة جامعة بيرزيت "إلي غياب شئون البيئة من وسائل الإعلام التي يتعرضون لها ، تداني البئ الوعي البيئي للطلبة ،

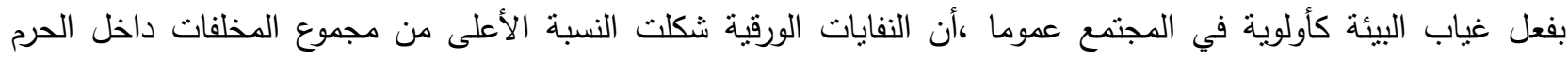

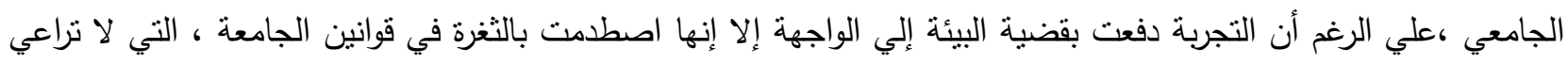

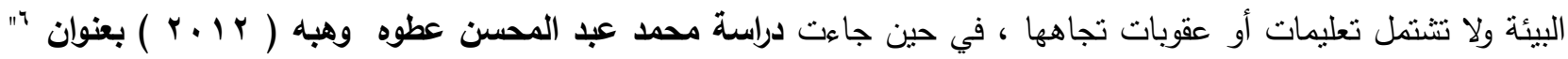

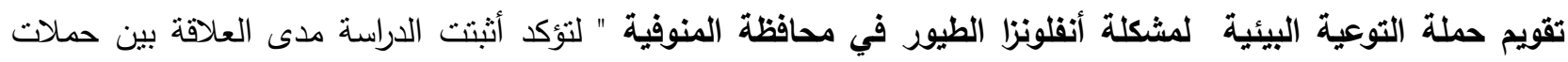
التوعية ودرجة الوعي البيئي لديهم ،أنتتت الدراسة وجود علاقة بين تعرض المبحوثين لحملات التوعية وبين الإقامة سواء

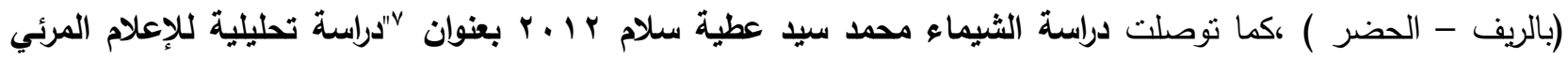

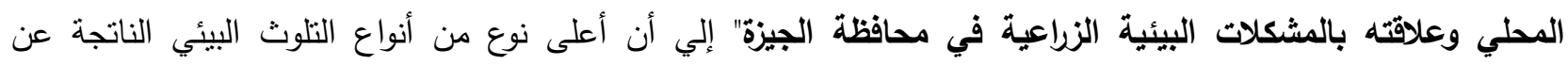

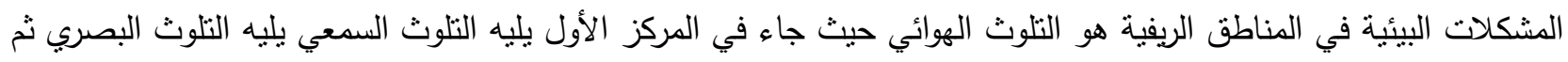

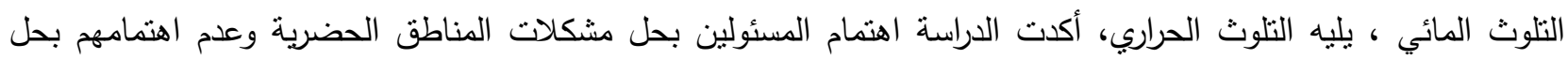

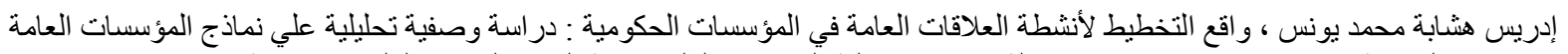

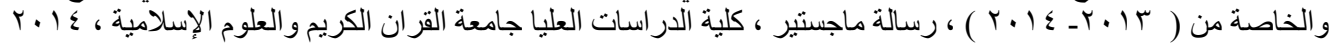

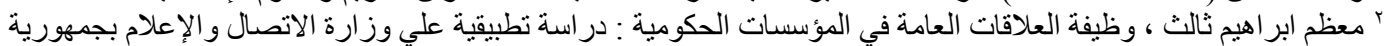

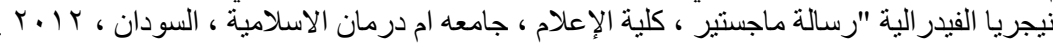

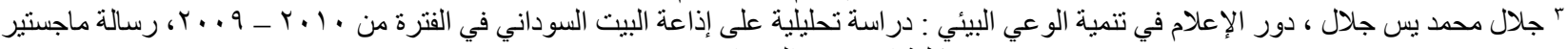

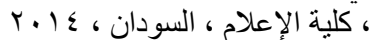

؛ عبدربه حامد العوفي ، بر امج العلاقات العامة ودور ها فى نشر الوعي البيئي بالمجتمع السعودي ، الإن، رسالة ماجستير ، كلية الآداب ، شعبة الإعلام ، جامعه

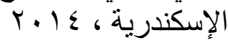

• عبد الباسط خلف ، دور وسائل الإعلام المتخصصة في تطوير الوعي البيئي : در اسة تطبيقية على طلبة جامعة بيرزيت ، رسالة ماجستير ، كلية الاداب

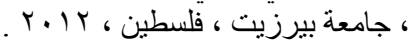

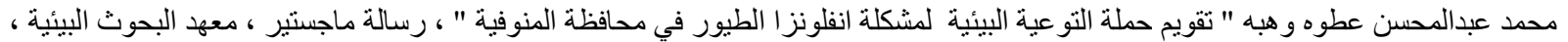

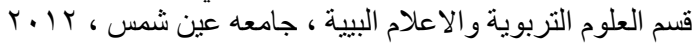

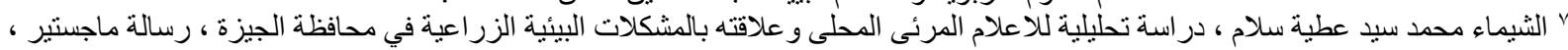

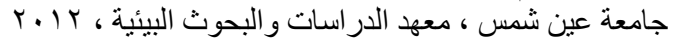


مشكلات المناطق الريفية ، في حين توصلت دراسة كرم الله حسين الأمين ( 11 ـ ب ) بعنوان '" دور العلاقات العامة في إنجاح

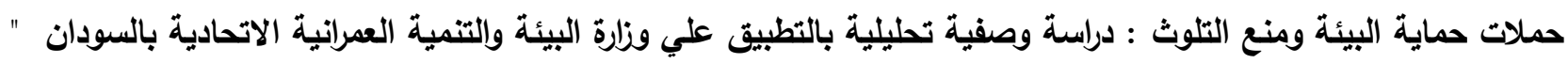

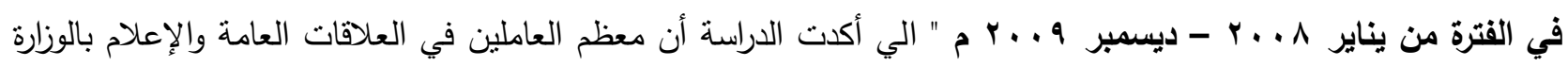
من غير المتخصصين في الإعلام والعلاقات العامة وهذا يضعف دورها ويقلل نشاطها ويحد من فعاليتها ويؤدي إلي سوء

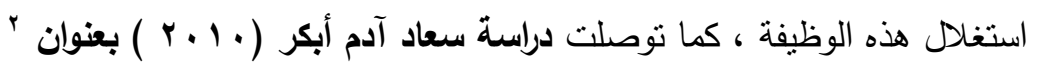

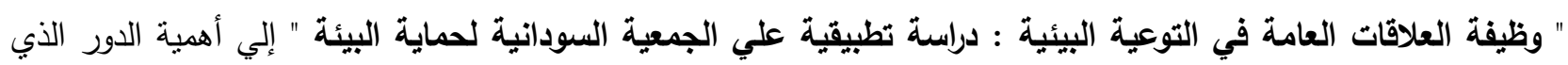

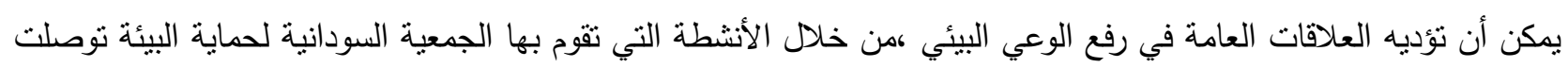

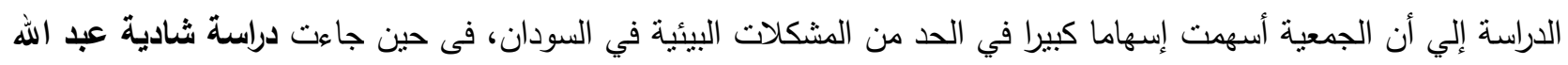

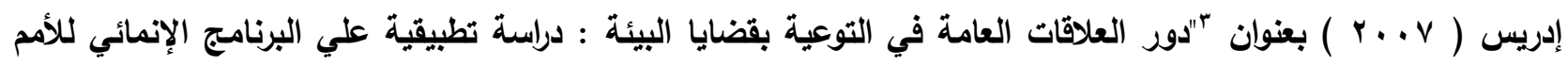

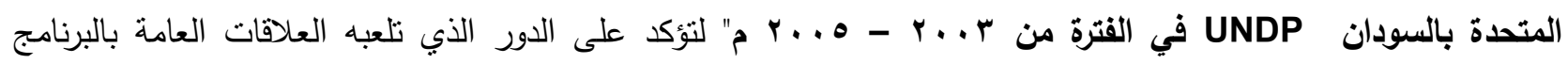
الإنمائي للأمم المتحدة لرفع الوعي البيئي في السودان ،كثفت الدراسة عن قلة الميزانيات المصدقة لوحدة الإعلام والعلاقات

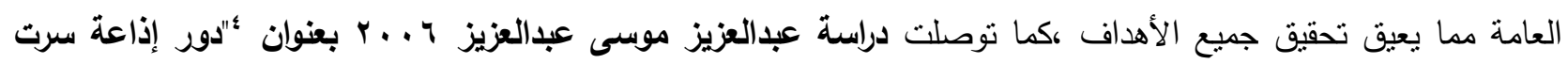

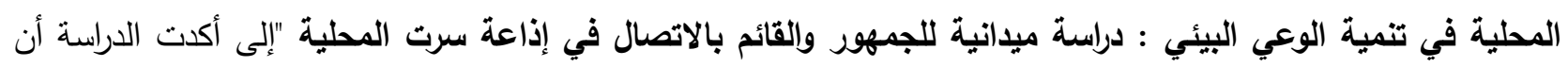

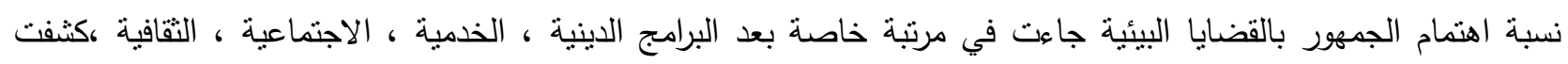

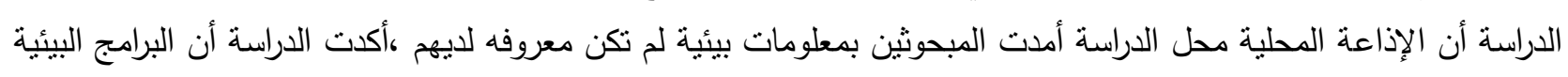
في الإذاعة ساعدت على تكوين سلوك ايجابي تجاه البيئة.

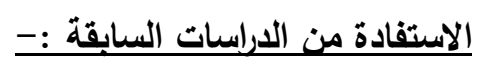

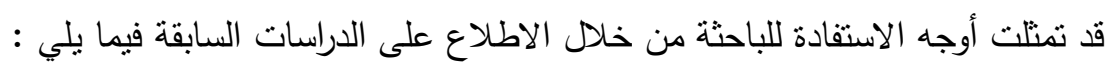

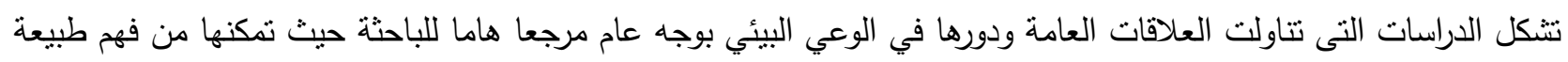

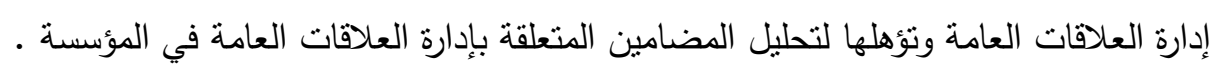
تعد بعض نتائج الدراسات السابقة في حد ذاتها حافزا لإجراء هذه الدراسة وذللك من خلاد الوقوف علدادة على احدث النتائج التى توصل

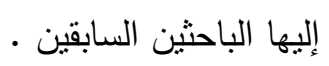

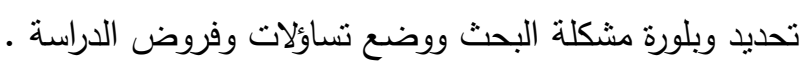
تحديد مجال الدراسة بالتركيز على دراسة إدارات العلاقات العامة في الوحدات المحلية ودورها في التوعية البيئية .

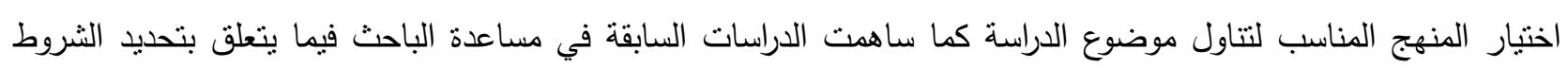

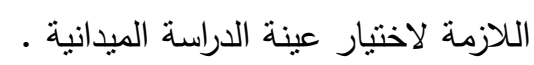

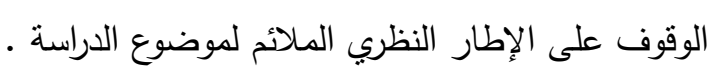
كما استفادت الدراسة الحالية من هذه الدراسات في تعريف مفاهيم الدراسة واختيار بعض أدوات الدات جمع البيانات ، ومقارنه النتائج · بناء أدوات الدراسة : استنيان خاص بالتعرف بأنشطة إدارات العلاقات العامة في الوحدات المحلية من قبل الموظفين ، واستبيان

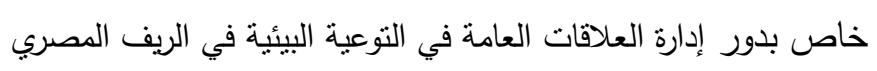

' كرم الله حسين الأمين ، دور العلاقات العامة في إنجاح حملات حماية البيئة ومنع التلوث ، رسالة ماجستير ، جامعة أم درمان كلية الإعلام ، السودان ، r. Yll

r سعاد ادم أبكر " وظيفة العلاقات العامة في التوعية البيئية : دراسة تطبيقية علي الجمعية السودانية لحماية البيئة " ، رسالة ماجستير جامعة أم درمان ،

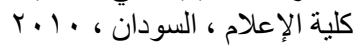

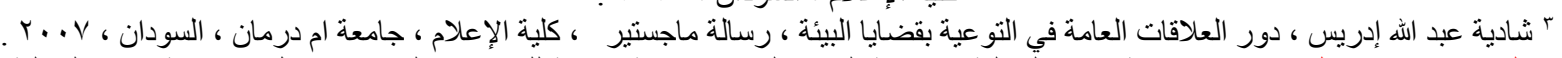

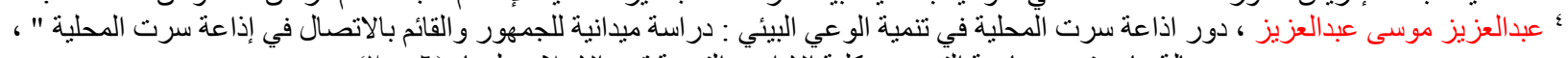

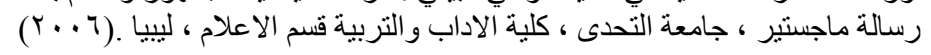




\section{نوع الدراسة ومنهجها}

تتنمي هذه الدراسة إلي الدراسات الوصفية وفى إطارها استخدمت الباحثة منهج المسح واستخدت في ذلك الاستيبان كأداة لجمع بيانات الدراسة.

عينة الاراسة

طبقت الدراسة على عينة عشوائية قوامها ( . ع ) مفرده من الجمهور المتردد على الوحدات المحلية لمركز ومدينة أثنمون بمحافظة

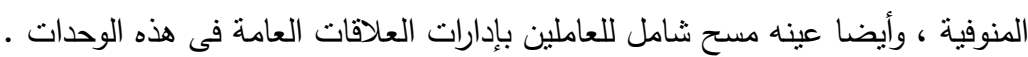
نتائج الاراسة :-

نتائج التحقق من صحة الفروض:

يحتوي هذا الجزء علي خلاصة ما نوصلت إليه الدراسة الراهنة من نتائج نطبيق الاستبيان، وسوف تتتاول الباحثة في هذا

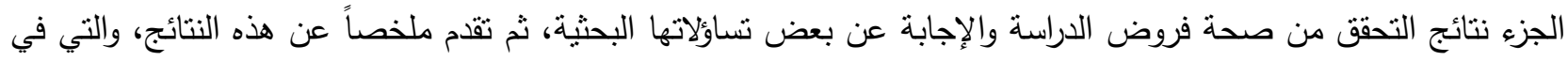
ضوئها يمكن طرح عدد من المقترحات والتوصيات. وفي ضوء أهداف الدراسة وفروضها سوف يتم عرض نتائج التحقق من صحة الفروض فيما يلي:-

الفرض الأول: توجد فروق ذات دلالة إحصائية بين متوسطات درجات المبحوثين على مقياس الوعى البيئى تبعا لاختلاف مستوى ممارسة أنشطة العلاقات العامة بالوحدات المحلية المختلفة.

تحليل التباين أحادي الاتجاه بين متوسطات درجات المبحوثين على مقياس الوعى البيئى تبعاً لاختلاف مستوى ممارسة أنثطة العلاقات العامة بالوحدات المحلية جدول رقم (1)

\begin{tabular}{|c|c|c|c|c|c|}
\hline الدلالة & قيمة ف & متوسط مجموع & الحرجة & مجموعات المريعات & مصدر التباين \\
\hline \multirow{3}{*}{ دالة *** } & \multirow{3}{*}{$\sum \wedge, 9 \uparrow}$. & rาqז,rq & r & 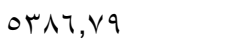 & بين المجموعات \\
\hline & & $00, \cdot 7$ & एवV & Y) $\triangle O V, O V$ & داخل المجموعات \\
\hline & & & ए११ & TVY $\varepsilon \varepsilon, r Y$ & المجمـوع \\
\hline
\end{tabular}

تثتير النتائج المتحصل عليها فى جدول رقم (1) إلي وجود فروق ذات دلالة إحصائية بين مجموعات المبحوثين الذين

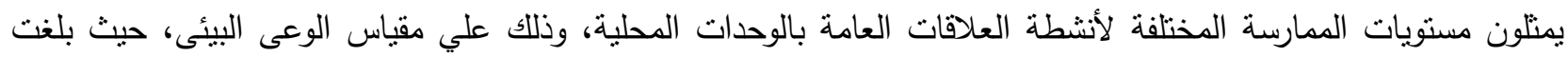

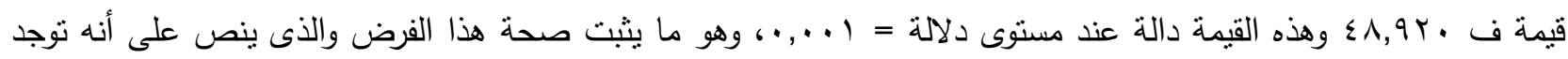
فروق ذات دلالة إحصائية بين منوسطات درجات المبحوثين على مقياس الوعى البيئى تبعا لاختلاف مسنوى ممارسة أنشطة العلاقات العامة بالوحدات المحلية المختلفة.

ولمعرفة مصدر ودلالة الفروق بين المتوسطات الحسابية لمجموعات المبحوثني، نم استخدام الاختبار البعدي L.S.D بطريقة أقل فرق معنوي. 
نتائج تحليل L.S.D لمعرفة الفروق بين المجموعات علي مقياس الوعى البيئى جدول (؟)

\begin{tabular}{|c|c|c|c|c|}
\hline المتوسط & منخفض & متوسط & مرتفع & المجموعات \\
\hline$\vee ৭, \wedge \varepsilon$ & & & - & مرتفع \\
\hline VY,IV & & - & $* * * \vee \vee, T V T$ & منوسط \\
\hline$v_{1}, \varepsilon 1$ & - & , vovi & $* * * \wedge, \varepsilon \Gamma \Gamma$ & منخفض \\
\hline
\end{tabular}

حيث اتضح أن هناك اختلافًا بين المبحوثين منخفضى مستوى الممارسة لأنشطة العلاقات العامة والمبحوثين مرتفعى مستوى الممارسة بفرق بين المتوسطين الحسابيين بلغ بrع, ^ لصالح المبحوثين مرتفعى مستوى الممارسة وهو فرق دال إحصائيا عند مستوى دلالة ا..,..، كما اتضح أن هناك اختلافًا بين المبحوثين متوسطى مستوى الممارسة لأنشطة العلاقات العامة والمبحوثين مرتفعى مستوى الممارسة بفرق بين المنوسطين الحسابيين بلغ VIVT,TV لصالح المبحوثين مرتفعى مستوى الممارسة وهو فرق دال إحصائيا عند مسنوى دلالة ا..,., ب، بينما ظهر أنه ليس هناك اختلافًا بين المبحوثين منخفضى مستوى الممارسة

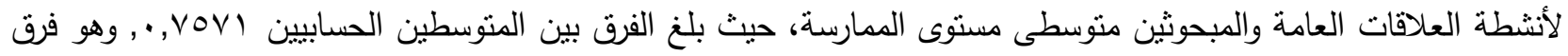
غير دال إحصائيا عند مستوى دلالة ه.,...

القرض الثانى: توحد فروق ذات دلالة إحصائية بين متوسطات درجات المبحثين على مقياس الوعى البئى تبعا لاختلاف مستوى التعرض لأنشطة العلاقات العامة بالوحدات المحلية المختلفة.

تحليل التباين أحادي الاتجاه بين متوسطات درجات المبحوثين على مقياس الوعى البيئى تبعا لاختلاف مستوى التعرض لأنثطة العلاقات

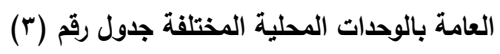

\begin{tabular}{|c|c|c|c|c|c|}
\hline الدالة الد & قيمة ف & المريعات & الحرية & مجموعات المريعات & مصدر التباين \\
\hline \multirow{3}{*}{ دالة ***\% } & \multirow{3}{*}{$r ד, r \leqslant V$} & Irro, vo & r & rTo1,0. & بين المجموعات \\
\hline & & $0 ., r T$ & $r \varepsilon$. & $|V| \cdot \wedge, \varepsilon \varepsilon$ & داخل المجموعات \\
\hline & & & $r \leqslant r$ & $19 \vee 09,9 \leq$ & المجمـوع \\
\hline
\end{tabular}

تثير بيانات الجدول السابق إلي وجود فروق ذات دلالة إحصائية بين مجموعات المبحوثين الذين يمثلون مستويات

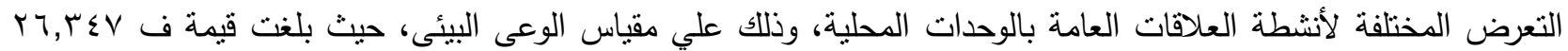
وهذه القيمة دالة عند مستوى دلالة = 1..,...، وهو ما يثبت صحة هذا الفرض والذى ينص على أنه توجد فروق ذات دلالة إحصائية بين متوسطات درجات المبحوثين على مقياس الوعى البيئى تبعا لاختلاف مستوى التعرض لأنشطة العلاقات العامة بالوحدات المحلية المختلفة.

L.S.D ولمعرفة مصدر ودلالة الفروق بين المتوسطات الحسابية لمجموعات المبحوثين، نم استخدام الاختبار البعدي بطريقة أقل فرق معنوي. تحليل التباين أحادي الاتجاه بين متوسطات درجات المبحوثين على مقياس الوعى البيئى تبعاً لاختلاف مستوى التعرض لأنثطة العلاقات العامة بالوحدات المحلية جدول (ع) الانجاه 


\begin{tabular}{|c|c|c|c|c|}
\hline المتوسط & منخفض & متوسط & مرتفع & المجموعات \\
\hline$\vee \wedge, I V$ & & & - & مرتفع \\
\hline$V Y, Y \wedge$ & & - & $* * * \circ, \wedge \wedge q$ & متوسط \\
\hline$v 1,1 r$ & - & $1,1 \leqslant r$ & $* * * V, \cdot r r$ & منخفض \\
\hline
\end{tabular}

حيث اتضح أن هناك اختلافًا بين المبحوثين منخفضى مستوى التعرض لأنشطة العلاقات العامة والمبحوثين مرتفعى

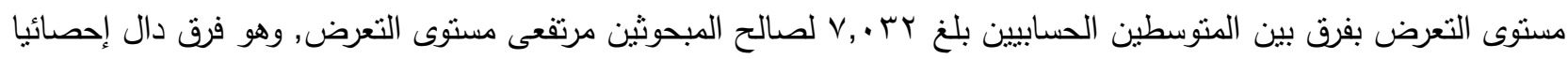

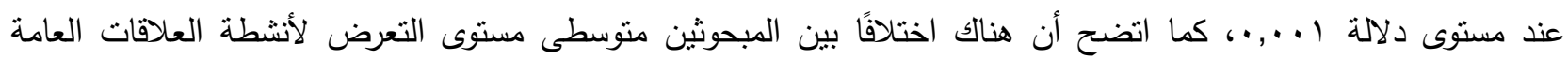
والمبحوثين مرتفعى مستوى التعرض بفرق بين المتوسطين الحسابيين بلغ ه هـ ه لصالح المبحوثين مرتفعى مستوى التعرض,

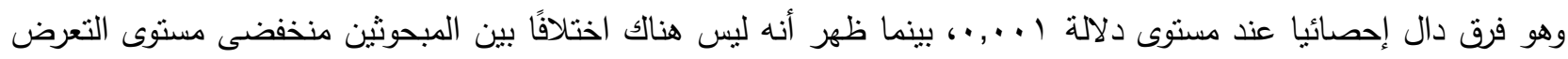

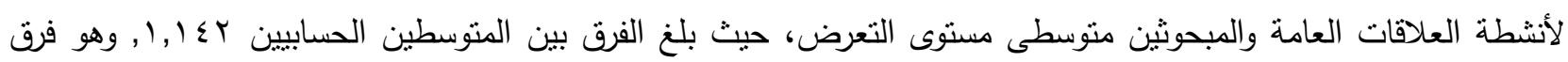
غير دال إحصائيا عند مستوى دلالة 0 .,. ..

الفرض الثالث: توجد فرق ذات دلالة إحصائية بين متوسطات درجات المبحوثين على مقياس التعرض لأنشطة العلاقات العامة بالوحدات المحلية تبعاً لاختلاف المتغيرات الإبموجرافية (النوع - الإقامة - المستوى التعليمى - السنئ).

ويقسم هذا الفرض إلى أريعة فروض فرعية هى: أ- لا توجد فروق ذات دلالة إحصائياً بين متوسطات درجات الذكور ومتوسطات درجات الإناث على مقياس التعرض لأنشطة العلاقات العامة بالوحدات المحلية.

نتائج اختبار (ت) لالالة الفروق بين المبحوثين في مستوى التعرض لأنثطة العلاقات العامة بالوحدات المحلية وفقا للنوع جدول (0)

\begin{tabular}{|c|c|c|c|c|c|c|}
\hline اللالالة & درجة الحرية & قيمة ت & المعياري & المتوسط & العدد & المجموعات \\
\hline \multirow{2}{*}{ غير دالة } & \multirow{2}{*}{$r \leqslant 1$} & \multirow{2}{*}{,, $1 \leqslant \wedge$} & צrו, & $r, 1 \cdot v$ & 114 & ذكور \\
\hline & & & צדצ', & r, ror & $10 \mathrm{~V}$ & إناث \\
\hline
\end{tabular}

تثنير نتائج اختبار "ت" فى الجدول السابق إلى عدم وجود فروق ذات دلالة إحصائية بين متوسطات درجات الذكور

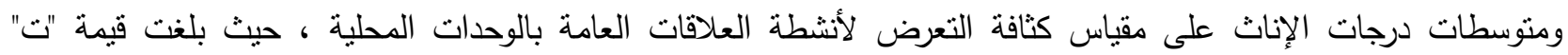

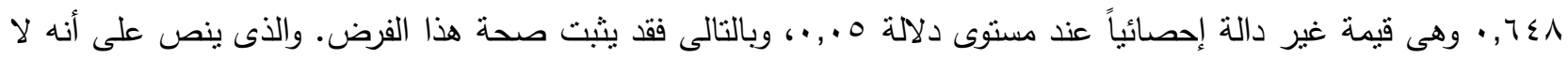
نوجد فروق ذات دلالة إحصائياً بين متوسطات درجات الذكور ومتوسطات درجات الإناث على مقياس التعرض لأنشطة العلاقات العامة بالوحدات المحلية.

ب- توجد فروق ذات دلالة إحصائياً بين متوسطات درجات مبحوثى الريف ومتوسطات درجات مبحوثى الحضر على مقياس التعرض لأنثطة العلاقات العامة بالوحدات المحلية لصالح مبحوثى الريف.

نتائج اختبار (ت) لالالة الفروق بين المبحوثُين في مستوى التعرض لأنثطة العلاقات العامة بالوحدات المحلية وفقا للإقامة جدول (؟) 


\begin{tabular}{|c|c|c|c|c|c|c|}
\hline الدلالة & درجة الحرية & قيمة ت & الانحراف & المتوسط & العدد & لمجموعات \\
\hline \multirow{2}{*}{ دالة } & \multirow{2}{*}{$\cdot, r \leq 1$} & \multirow{2}{*}{$\varepsilon$} & סצו, & r,rir & 10. & ريف \\
\hline & & & - TY & $1,9 \wedge \varepsilon$ & 194 & حضر \\
\hline
\end{tabular}

تتشير نتائج اختبار "ت" فى الجدول السابق إلى وجود فروق ذات دلالة إحصائية بين منتسطات درجات مبحوثى الريف

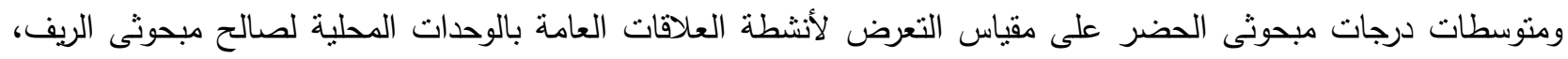

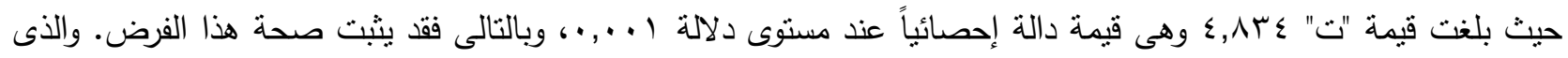
ينص على أنه توجد فروق ذات دلالة إحصائياً بين متوسطات درجات مبحوثى الريف ومتوسطات درجات مبحوثى الحضر على دلى

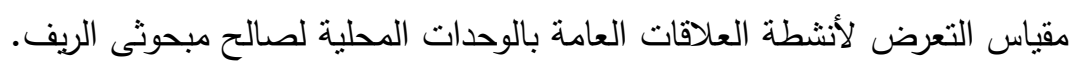

ج- توجد فروق ذات دلالة إحصائية بين متوسطات درجات المبحوثين على مقياس التعرض لأنثطة العلاقات العامة بالوحدات المحلية تبعا لاختلاف المستوى التعليمى. داله

تحليل التباين أحادي الاتجاه بين متوسطات درجات المبحوثين على مقياس التعرض لأنشطة العلاقات العامة بالوحدات

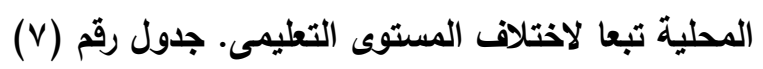

\begin{tabular}{|c|c|c|c|c|c|}
\hline الدلالة & قيمة ف & متوسط مجموع & درجة الحرية & مجموعات المريعات & مصدر التباين \\
\hline \multirow{3}{*}{ دالة" } & \multirow{3}{*}{$r, 1 \wedge \varepsilon$} & $1, r$ & r & $r, T$ & بين المجموعات \\
\hline & & $\cdot, \varepsilon)$ & $r \leqslant$. & $1 \% q, v \varepsilon$ & داخل المجموعات \\
\hline & & & $r \leqslant r$ & דr, & المجمـوع \\
\hline
\end{tabular}

تتثير بيانات الجدول السابق إلي وجود فروق ذات دلالة إحصائية بين مجموعات المبحوثين الذين يمنلون المستويات

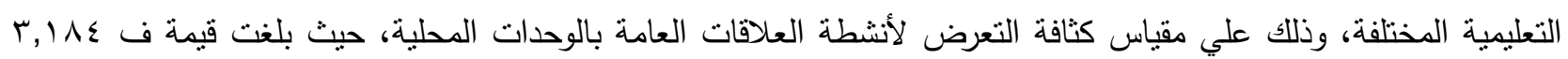
وهذه القيمة دالة عند مستوى دلالة = 0.,. ، وهو ما يثبت صحة هذا الفرض والذى ينص على أنه نوجد فروق ذات دلالة إحصائية بين متوسطات درجات المبحوثين على مقياس التعرض لأنشطة العلاقات العامة بالوحدات المحلية تبعا لاختلاف المستوى التعليمى. ولمعرفة مصدر ودلالة الفروق بين المتوسطات الحسابية لمجمعات المبحوثين، نم استخدام الاختبار البعدي L.S.D

نتائج تحليل L.S.D لمعرفة الفروق بين المجموعات علي مقياس التعرض لأنثطة العلاقات العامة بالوحدات المحلية جدول (^)

\begin{tabular}{|c|c|c|c|c|}
\hline المتوسط & أقل من جامعى & جامع & أعلى من جامعى & المجموعات \\
\hline דזו, & & & - & أعلى من جامعى \\
\hline$r, \mid \wedge \Lambda$ & & - & $\cdot, .0 Y \leqslant$ & 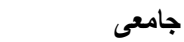 \\
\hline
\end{tabular}




\begin{tabular}{|c|c|c|c|c|}
\hline $1,9 \vee 0$ & - & * & $\cdot, 1711$ & أقل من جامعى \\
\hline
\end{tabular}

حيث اتضح أن هناك اختلافًا بين المبحوثين ذوى مستوى التعليم أقل من جامعى والمبحوثين ذوى مستوى التعليم الجامعى

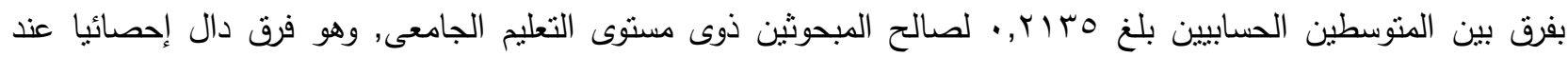

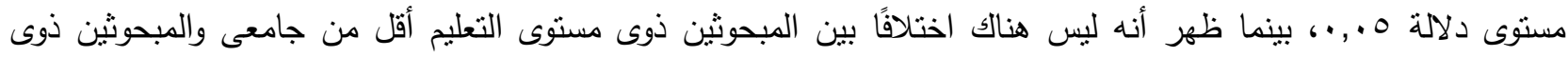

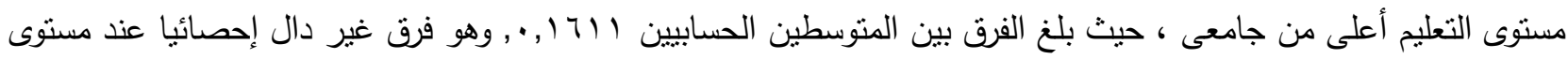
دلالة ه ., ..، كما ظهر أنه ليس هناك اختلافًا بين المبحوثين ذوى مستوى التعليم الجامعى والمبحوثين ذوى مستوى التعليم أعلى لئى

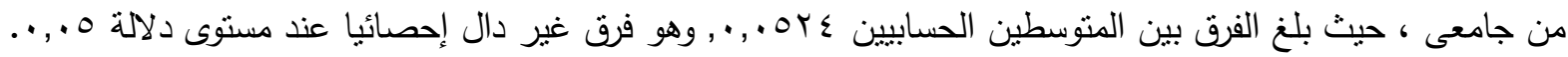
د - توجد فروق ذات دلالة إحصائية بين متوسطات درجات المبحوثين على مقياس التعرض لأنشطة العلاقات العامة بالوحدات المحلية تبعا لاختلاف السن.

تحليل التباين أحادي الاتجاه بين متوسطات درجات المبحوثين على مقياس التعرض لأنشطة العلاقات العامة بالوحدات المحلية تبعا

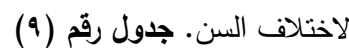

\begin{tabular}{|c|c|c|c|c|c|}
\hline الالالة & قيمة ف & متوسط مجموع & الحرية & مجموعات المربعات & مصدر التباين \\
\hline \multirow{3}{*}{ غير دالة } & \multirow{3}{*}{$\cdot, 071$} & $\cdot, 01$ & r & 1,10 & بين المجموعات \\
\hline & & $\cdot, \leqslant T$ & $r \varepsilon$. & $1 \leqslant 1, r$. & داخل المجموعات \\
\hline & & & $r \leqslant r$ & $1 \leqslant r, \pi 4$ & المجمـوع \\
\hline
\end{tabular}

تشير بيانات الجدول السابق إلي عدم وجود فروق ذات دلالة إحصائية بين مجموعات المبحوثين الذين يمثلون المستويات

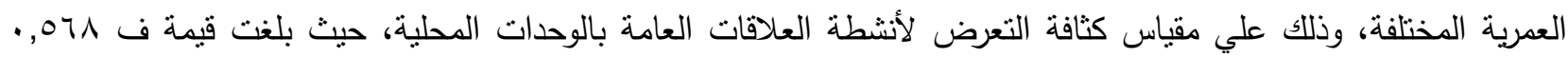
وهذه القيمة غير دالة عند مستوى دلالة = 0., .، وهو ما يثبت صحة هذا الفرض والذى ينص على أنه توجد فروف ذات دلالة إحصائية بين متوسطات درجات المبحوثين على مقياس التعرض لأنشطة العلاقات العامة بالوحدات الدحلية تبعا لاختلاف السن. الفرض الرابع: توجد فروق ذات دلالة إحصائبة بين متوسطات درجات المبحوثين على مقياس الوعى البيئيى تبعاً لاختلاف المتغيرات الايموجرافية (النوع - الإقامة - المستوى التعليمى - السنئ).

ويقسم هذا الفرض إلى أربعة فروض فرعية هى: أ- - لا توجد فروق ذات دلالة إحصائياً بين متوسطات درجات الأكور ومتوسطات درجات الإناث على مقياس الوعى البيئى. جلول ( • 1) نتائج اختبار (ت) لدلالة الفروق بين المبحوثين في مستوى الوعى البيئى وفقا للنوع

\begin{tabular}{|c|c|c|c|c|c|c|}
\hline الدلالة & درجة الحرية & قيمة ت & الانحراف & المتوسط & العدد & المجموعات \\
\hline غير دالة & ra1 & $\cdot, \cdot r r$ & $\Lambda, r r$ & $V \varepsilon, Y \wedge$ & rY. & ذكور \\
\hline
\end{tabular}




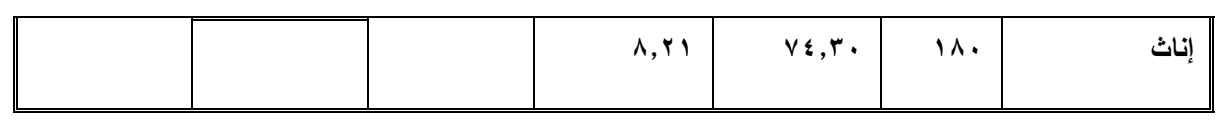

تثتير نتائج اختبار "ت" فى الجدول السابق إلى عدم وجود فروق ذات دلالة إحصائية بين منوسطات درجات الذكور ومتوسطات درجات

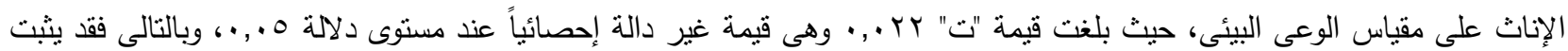

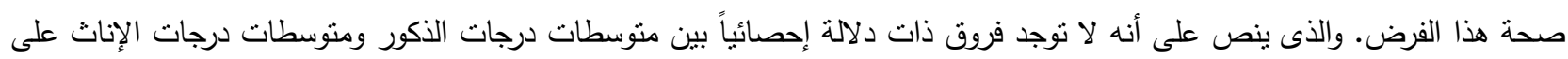
مقياس الوعى البيئى.

ب- لا توجد فروق ذات دلالة إحصائياً بين متوسطات درجات مبحوثى الريف ومتوسطات درجات مبحوثى الحضر على مقياس الوعى البيئى.

نتائج اختبار (ت) لالالة الفروق بين المبحوثين في مستوى الوعى البيئى وفقا للإقامة جدول (11)

\begin{tabular}{|c|c|c|c|c|c|c|}
\hline الدلالة & درجة الحرية & قيمة ت & الالمعراف & المتوسط & العدد & المجموعات \\
\hline \multirow{2}{*}{ غير دالة } & \multirow{2}{*}{ (1), } & \multirow{2}{*}{$\cdot, \ldots$} & $\Lambda, r$. & $V \varepsilon, Y \wedge$ & lor & ريف \\
\hline & & & ג, ד & $v \varepsilon, r q$ & $r \leqslant \Lambda$ & حضر \\
\hline
\end{tabular}

تتثبر نتائج اختبار "ت" فى الجدول السابق إلى عدم وجود فروق ذات دلالة إحصائية بين متوسطات درجات مبحوثى الريف

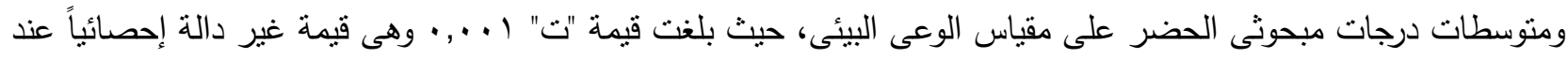
مستوى دلالة ه.,. .، وبالتالى فقد يثتت صحة هذا الفرض. والذى ينص على أنه لا توجد فروق ذات دلالة إحصائياً بين متوسطات درجات مبحوثى الريف ومتوسطات درجات مبحوثى الحضر على مقياس الوعى البيئى.

ج- لا توجد فروق ذات دلالة إحصائية بين متوسطات درجات المبحوثين على مقياس الوعى البيئى تبعا لاختلاف المستوى التعليمى.

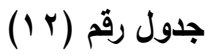

تحليل التباين أحادي الاتجاه بين متوسطات درجات المبحوثين على مقياس الوعى البيئى تبعا لاختلاف المستوى التعليمى.

\begin{tabular}{|c|c|c|c|c|c|}
\hline الدلالة & ق قيمة ف & متوسط مجموع & الحرية & مجموعات المريعات & مصدر التباين \\
\hline \multirow{3}{*}{ غير دالة } & \multirow{3}{*}{$1, \ldots 9$} & TA, qY & r & $1 \pi v, \wedge 0$ & بين المجموعات \\
\hline & & $\neg \Lambda, Y \wedge$ & rav & YVI.7,01 & داخل المجموعات \\
\hline & & & r99 & $T V Y \leqslant \leqslant, r Y$ & المجموع \\
\hline
\end{tabular}

تثتير بيانات الجدول السايق إلي عدم وجود فروق ذات دلالة إحصائية بين مجموعات المبحوثين الذين يمثلون المستويات

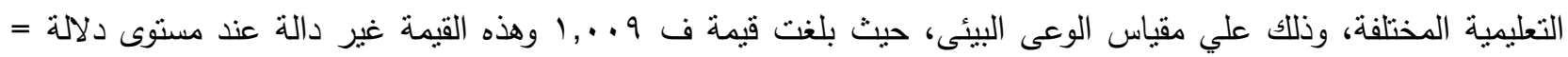
ه.,.، ، وهو ما يثبت صحة هذا الفرض والذى ينص على أنه لا توجد فروق ذات دلالة إحصائية بين منوسطات درجات المبحوثين على مقياس الوعى البيئى تبعا لاختلاف المستوى التعليمى. 
د- لا توجد فروق ذات دلالة إحصائية بين متوسطات درجات المبحوثين على مقياس الوعى البيئى تبعا لاختلاف السن. جدول رقم (r) ت الحليل التباين أحادي الاتجاه بين متوسطات درجات المبحوثين على مقياس الوعى البيئى تبعا لاختلاف السن.

\begin{tabular}{|c|c|c|c|c|c|}
\hline الدلالة & قيمة ف & متوسط مجموع & الحرجة & مجموعات المربعات & مصدر التباين \\
\hline \multirow{3}{*}{ غير دالة } & \multirow{3}{*}{$\cdot, 071$} & 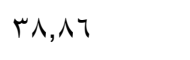 & r & $v \vee, V I$ & بين المجموعات \\
\hline & & $\Upsilon \wedge, \varepsilon r$ & rqv & $r V \backslash 77,70$ & داخل المجموعات \\
\hline & & & rq9 & $Y V T \leq \varepsilon, Y T$ & المجمـوع \\
\hline
\end{tabular}

تشير بيانات الجدول السابق إلي عدم وجود فروق ذات دلالة إحصائية بين مجموعات المبحوثين الذين يمثلون المستويات

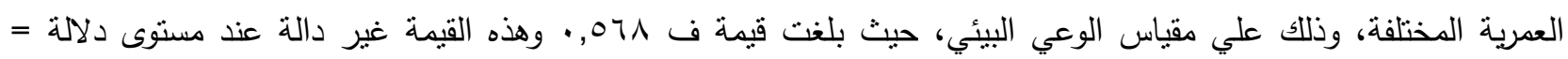
ه.,.،، وهو ما يثبت صحة هذا الفرض والذي ينص على أنه لا توجد فروق ذات دلالة إحصائية بين متوسطات درجات المبحوثين على مقياس الوعي البيئي تبعا لاختلاف السن.

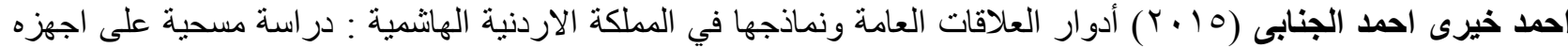
العلاقات العامة في المؤسسات الإعلامية العامة و الخاصة ، رسالة ماجستير ، كلية الاعلام ، جامعة الثرق الأوسط ،

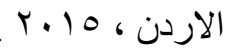

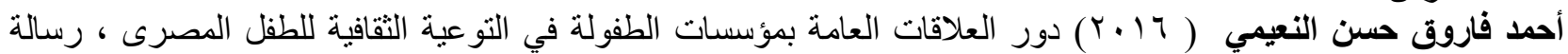

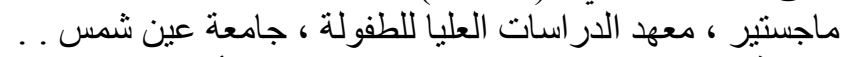

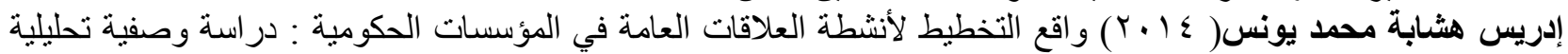

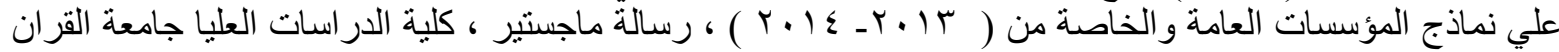

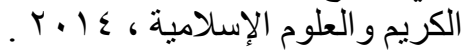

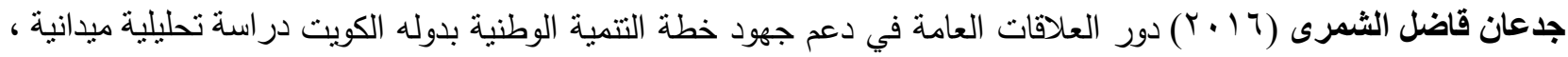

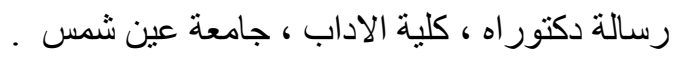
جلال محمد يس جلال( ـ ( • ب) دور الإعلام في تنمية الوعي البيئي : دراسة تحليلية على إذاعة البيت السوداني في الفترة من

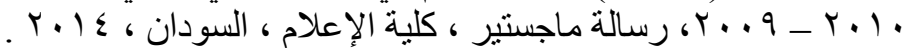
سعاد الدم أبكر " وظيفة العلاقات العامة في التوعية البيئية : دراسة تطبيقية الإنية علي الجمعية السودانية لحماية البيئة " ، رسالة

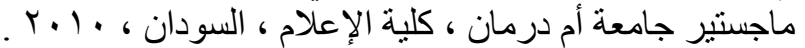

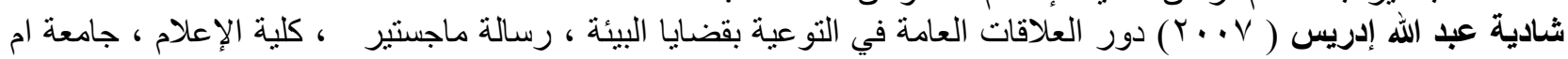

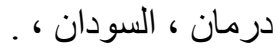

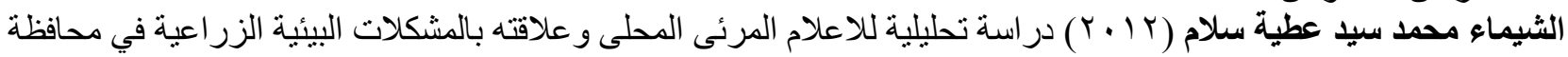

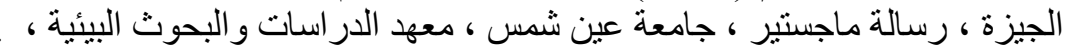

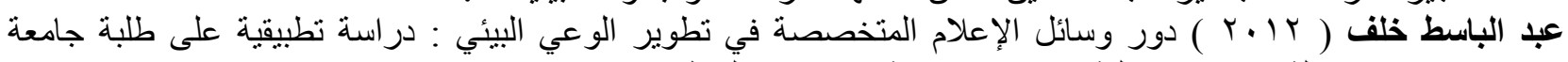

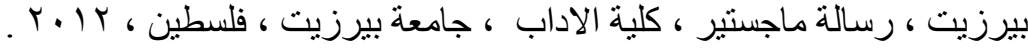

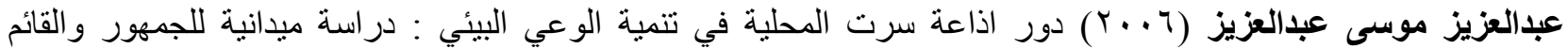

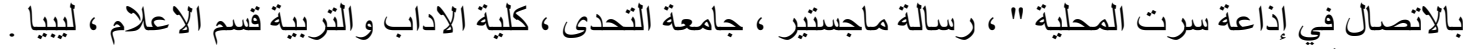

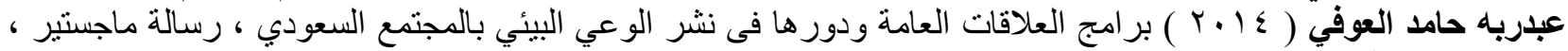

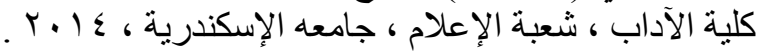




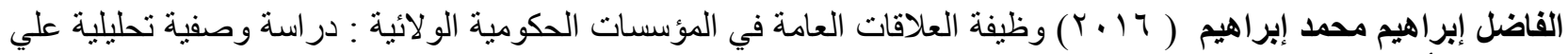

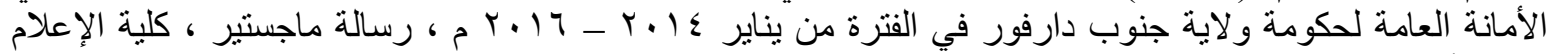
جامعة أم درمان الإسلامية

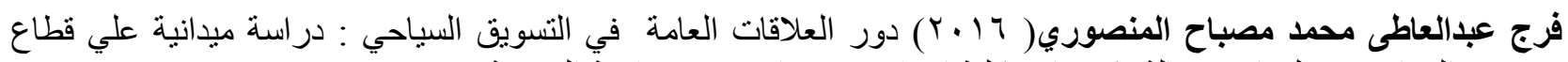

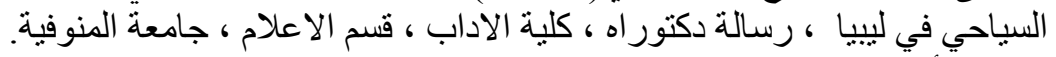

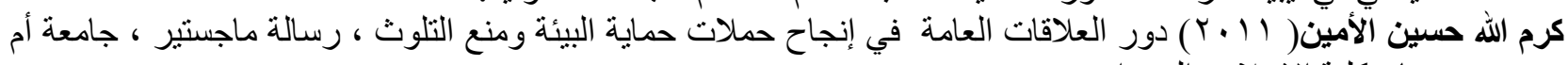

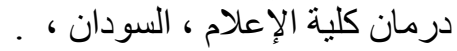

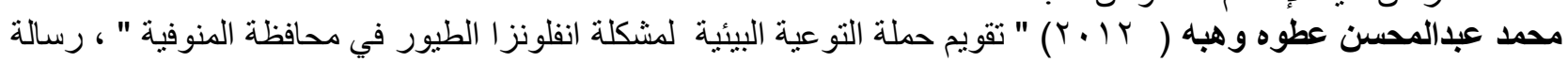

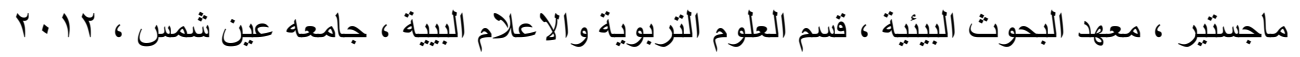

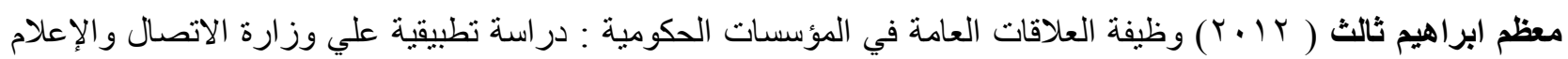

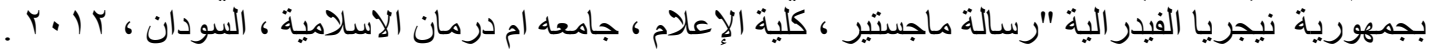

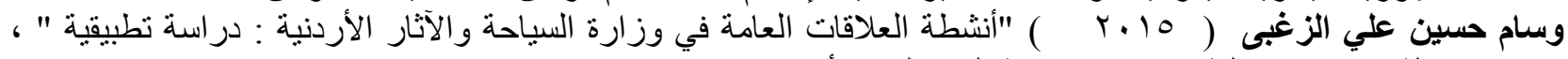

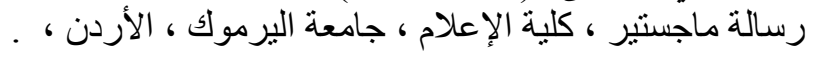

